\title{
Persepsi Guru dan Siswa SD di Yogyakarta terhadap Program Conservation Scout
}

\author{
Wahyu Wido Sari \\ Pendidikan Guru Sekolah Dasar, FKIP, Universitas Sanata Dharma \\ Tromol Pos 29, Mrican, Yogyakarta \\ surat elektronik: w.widasari@gmail.com
}

\begin{abstract}
ABSTRAK
Penanaman karakter cinta lingkungan dan pemahaman akan pentingnya konservasi perlu dilakukan sejak dini. Program conservation scout atau pandu konservasi menawarkan edukasi dan empowering siswa SD mengenai konservasi. Kegiatan ini bertempat di Pusat Studi Lingkungan, Universitas Sanata Dharma dan melibatkan 38 SD di Yogyakarta. Peserta conservation scout terdiri dari 32 guru dan 70 siswa SD.

Penelitian ini bertujuan untuk melihat respon sekolah, persepsi guru, persepsi siswa, dan keberhasilan sekolah dalam mendukung program conservation scout. Metode yang digunakan adalah action reseach, survey, dan diskriptif kualitatif. Instrumen yang digunakan adalah kuesioner dengan hasil validasi sangat baik.

Sekolah memberikan respon sangat positif ( $84 \%)$ terhadap program conservation scout, dari 38 sekolah yang diundang, ada 32 sekolah yang mengikuti program ini. Guru memberikan persepsi negatif $(2,50)$, bukan pada esensi program melainkan pada teknik pelaksanaan program. Siswa memberikan persepsi positif (3,5I) dan 36 dari 70 siswa berhasil melakukan peer tutoring dan kampanye mengenai konservasi. Ada 53, I2\% SD yang siswanya menjadi duta konservasi lingkungan.
\end{abstract}

Kata kunci: conservation scout, pendidikan karakter, konservasi

\section{Pendahuluan}

Perilaku pengrusakan lingkungan dan ketidaksadaran masyarakat untuk tidak menjaga lingkungan semakin tinggi hari-hari ini. Jika diamati lebih lanjut, perilaku pengrusakan lingkungan tidak sebatas pada pembabatan hutan secara liar, tetapi sudah mengakar pada perilaku manusia Indonesia dalam kehidupan sehari-hari. Misalnya saja, berdasarkan observasi, ada mahasiswa yang meninggalkan sampah di ruang kuliah atau di sembarang tempat di lingkungan kampus. Lebih luas lagi, muncul genangan air atau banjir mendadak di jalan-jalan tertentu di Yogyakarta jika hujan deras tiba akibat hilangnya daerah resapan air yang berubah menjadi mall dan hotel. Jika hal ini dibiarkan terus, maka generasi yang akan datang akan menanggung lingkungan yang rusak dan tidak memiliki kepedulian untuk mempertahankannya. Oleh karena itu pendidikan mengenai konservasi lingkungan perlu dilakukan sejak dini, khususnya pada jenjang SD.

Penanaman kembali karakter cinta lingkungan dan pemahaman akan pentingnya konservasi perlu dilakukan melalui pendidikan kepada generasi muda (anak-anak). Davis (1998) menuliskan bahwa hubungan antara anak dengan alam sekitarnya merupakan landasan yang penting untuk membangun hubungan yang baik antara manusia dengan alam. Secara alami, anak adalah penjelajah alami. Mereka mengobservasi dan meneliti lingkungan di sekitar mereka secara alami dan belajar darinya (learning by doing).

Pusat Studi Lingkungan (PSL) yang dimiliki oleh Universitas Sanata Dharma menawarkan media pembelajaran yang sangat menarik bagi anak-anak. Di PSL, dikembangbiakkan burung-burung langka, hutan jati, lobster, dan tanaman obat. Disana juga dipelihara reptil dan ada pelestarian kopi dari berbagai tempat di Indonesia. Bahkan, ada pengolahan biogas juga yang bisa menjadi sarana bagi anak-anak belajar akan energi alternatif. Pembelajaran berbasis pada pelestarian lingkungan ini akan dikemas dalam bentuk Conservation scout atau pramuka berbasis konservasi. Anak-anak diharapkan menjadi agen dalam mewujudkan generasi yang peduli terhadap lingkungan melalui tindakan nyata.

Penelitian ini bertujuan untuk melihat persepsi guru dan siswa dari 38 SD di Yogyakarta yang menjadi peserta program conservation scout. Program Conservation scout dilakukan selama 3 kali dan diakhiri 
dengan kegiatan peer tutoring dan kampanye di SD masing-masing peserta.

\section{Metode Penelitian}

Penelitian ini berjenis action research dengan survey dan diskriptif kualitatif. Populasi dalam penelitian ini adalah 38 SD mitra PGSD Universitas Sanata Dharma di wilayah Yogyakarta baik SD Negeri maupun SD Swasta. Jumlah pesertanya adalah 38 guru pendamping dan 76 siswa.

\section{Definisi Operasional}

I. Conservation scout adalah program pengenalan konservasi dan karakter cinta lingkungan pada siswa sekolah dasar di Pusat Studi Lingkungan, Universitas Sanata Dharma.

2. Siswa sekolah dasar adalah anak yang berusia antara 6I2 tahun dan sedang mengikuti pendidikan di sekolah dasar baik negeri maupun swasta.

3. Karakter cinta lingkungan adalah karakter peduli pada lingkungan: mengkampanyekan cara memelihara lingkungan, mengajari teman sebaya (peer tutoring) mengenai cara memelihara lingkungan atau hal yang berkaitan dengan konservasi.

\section{Instrumen Penelitian}

Instrumen penelitian ini berupa kuesioner persepsi guru dan siswa peserta conservation scout. Kuesioner divalidasi oleh ahli penelitian pendidikan dengan ketentuan skor I-4 (sangat baik, baik, kurang, kurang sekali). Kuesioner tersebut berskala I-4 dengan ketentuan sangat setuju, setuju, sangat tidak setuju, dan tidak setuju pada Tabel I.

Dua hal yang divalidasi yaitu: isi (content validity) dan konstruk (contruct validity).

Tabel I. Konversi Nilai Skala Empat Berdasarkan Penilaian Acuan

\begin{tabular}{cc}
\hline Kategori & Interval Skor \\
\hline Sangat Baik & $\mathrm{X} \geq 3,40$ \\
\hline Baik & $2,60<\mathrm{x} \leq 3,40$ \\
\hline Cukup Baik & $\mathrm{I}, 79<\mathrm{x} \leq 2,60$ \\
\hline Kurang Baik & $\mathrm{X} \leq \mathrm{I}, 79$ \\
\hline
\end{tabular}

\section{Teknik Pengumpulan Data}

Kuesioner disebarkan pada guru dan siswa peserta Conservation scout setelah kegiatan Conservation scout selesai berlangsung. Kuesioner diisi secara mandiri oleh guru dan siswa (tanpa bantuan dari peneliti) kemudian dikembalikan pada hari yang sama. Selanjutkan kuesioner dikumpulkan dianalisa datanya.

Hal pertama dalam analisis data adalah pengecekan identitas responden, pengecekan kelengkapan pengisian dan pengecekan lain yang bertujuan supaya data yang dikumpulkan maksimal. Langkah kedua adalah tabulasi, yaitu pengelompokan data dalam tabel, coding, kemudian scoring. Bobot alternatif jawaban yaitu pernyataan positif
SS (4), S (3), TT (2), dan STS (I). Pernyataan negatif diberi bobot SS (I), S (2), TS (3), STS (4).

Alat analisis data berupa mean (rata-rata) dari score yang diperoleh. Ada 4 kategori persepsi responden yaitu: sangat negatif, negatif, positif, dan sangat positif (Arikunto, 2005). Rumus yang digunakan dalam penelitian ini:

$$
\begin{aligned}
& \mathrm{X}=\Sigma \mathrm{X} / \mathrm{N} \\
& \text { keterangan: } \\
& \mathrm{X}=\text { rata-rata hitung } \\
& \Sigma=\text { jumlah semua nilai kuesioner } \\
& \mathrm{N}=\text { Jumlah responden } \\
& \text { Grand mean }(\mathrm{X})=\text { total rata-rata hitung/ jumlah } \\
& \text { pertanyaan. Langkah selanjutnya data dijabarkan dalam } \\
& \text { bentuk kalimat yang mengandung kesimpulan. }
\end{aligned}
$$

\section{Hasil dan Pembahasan}

\section{Respon Sekolah Dasar Mitra PGSD terhadap Program Conservation Scout}

Peneliti mengundang 38 sekolah dasar di wilayah Yogyakarta yang merupakan mitra PGSD (mempunya MoU kerjasama dengan PGSD). Ada 32 sekolah yang menanggapi surat undangan tersebut dengan mengirimkan peserta $(2-4$ orang siswa) dan I orang guru pendamping. Keenam sekolah yang tidak mengirimkan siswa untuk menjadi peserta memberikan alasan bahwa jarak tempuh sekolah dengan Pusat Studi Lingkungan sangat jauh dan kegiatan bertepatan dengan ujian tengah semester ganjil 20I4-20I5.

Persentase respon sekolah dasar mitra PGSD terhadap program Conservation scout dapat dilihat pada Gambar I.

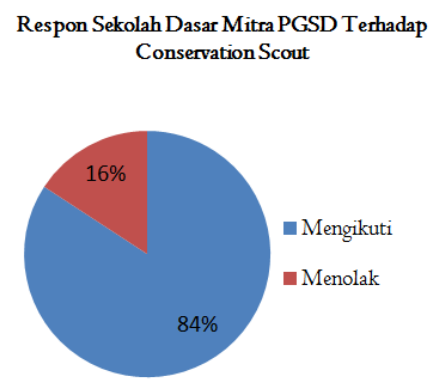

Gambar I. Persentase Respon Sekolah terhadap Conservation Scout

Sekolah dasar mitra PGSD memberikan respon yang sangat baik terhadap tawaran program conservation scout. Kepala sekolah menyadari pentingnya memperkuat karakter cinta lingkungan dan pengetahuan mengenai konservasi pada anak-anak. Selain akan menambah kredit bagi sekolah yang kepedulian mengenai lingkungan hidup, siswa-siswa SD juga antusias mengikuti kegiatan yang akan menjadikan mereka duta konservasi lingkungan jika mereka berhasil melakukan kampanye dan peer tutoring. Peneliti menerima pertanyaan dari hampir semua kepala sekolah seandainya mereka boleh mengirimkan lebih dari 2 peserta. Hal ini sesuai dengan hasil penelitian Thathong dan Leopenwong (2014) yang menyatakan bahwa sebagian besar siswa sekolah dasar 
dan remaja peduli akan pentingnya konservasi lingkungan karena yang terjadi di lingkungan berefek pada hidup mereka.

\section{Persepsi Guru dan Siswa terhadap Conservation Scout}

Instrumen yang berhasil disusun peneliti dalam penelitian ini berupa kuesioner terhadap guru dan siswa. Kuesioner untuk guru dan siswa tersebut berisi I5 pernyataan dengan rincian 13 pernyataan positif dan 2 pernyataan negatif. Kisi-kisi kuesioner yang dibagikan pada guru adalah kejelasan kegiatan conservation scout, kejelasan kegiatan praktikum conservation scout, kejelasan keterkaitan Conservation scout dengan lingkungan hidup, dan kesiapan guru menjadi pendamping duta konservasi di sekolah. Kisi-kisi kuesioner yang dibagikan pada siswa adalah kejelasan kegiatan conservation scout, kejelasan kegiatan praktikum conservation scout, kejelasan keterkaitan Conservation scout dengan lingkungan hidup, dan kesiapan siswa menjadi duta lingkungan hidup.

Conservation scout dilaksanakan dalam 3 tahap atau 3 kali pertemuan. Pertemuan pertama dilakukan pada tanggal 2 Oktober 2014 dengan kegiatan eksperimen berbasis lingkungan hidup dan minitrip di PSL. Diakhir pertemuan, peserta diminta melakukan presentasi spontan mengenai kegiatan eksperimen yang sudah dilakukan. Pertemuan kedua dilakukan pada tanggal I6 Oktober 2014 dengan kegiatan praktik membuat awetan bioplastik dan mengenal konservasi reptil. Pertemuan terakhir, yaitu tanggal 23 Oktober 20I4, peserta diajak untuk melakukan studi kasus mengenai pencemaran, lalu mereka diminta membuat poster untuk dipresentasikan. Poster berisi ajakan untuk mengkonservasi lingkungan berdasarkan kasus pencemaran yang sudah diutarakan.

Keberhasilan kegiatan Conservation scout saat siswa berani melakukan kampanye dan peer tutoring di sekolah masing-masing dalam rentang waktu 2 minggu setelah kegiatan di PSL. Peserta atau siswa yang mampu melaksanakan kampanye dan peer tutoring mendapat penghargaan sebagai duta konservasi lingkungan.

Peneliti mengukur persepsi guru dan siswa dengan menggunakan instrumen berupa kuesioner. Pemilihan instrumen ini berdasarkan pemikiran bahwa kuesioner lebih mudah diisi oleh siswa SD dan cepat diolah datanya. Hal ini sesuai dengan Anwar (1997) yang menyatakan bahwa kuesioner merupakan instrumen pengumpulan data yang sangat fleksibel dan relatif mudah digunakan. Akurasi dan kecermatan data hasil pengukuran tergantung pada validitas alat ukurnya. Hasil validasi ahli dari kuesioner yang digunakan dapat dilihat pada Tabel 2.

Tabel 2. Hasil Validasi Ahli terhadap Kuesioner

\begin{tabular}{ccl}
\hline Kuesioner & Rata-Rata Skor & Kategori \\
\hline Persepsi Guru & 3,73 & Sangat baik \\
\hline Persepsi Siswa & 3,66 & Sangat baik \\
\hline
\end{tabular}

Skala pengukuran kuesioner adalah I-4 dengan ketentuan sangat setuju, setuju, sangat tidak setuju, dan tidak setuju. Kuesioner berbentuk skala bertingkat adalah sebuah pernyataan yang diikuti oleh kolom-kolom yang menunjukkan tingkatan-tingkatan (Arikunto, 2010).

Kuesioner dibagikan guru dan siswa pada pertemuan program conservation scout. Ada 32 sekolah yang mengirimkan 2 siswa dan I guru untuk mengikuti conservation scout, sehingga ada 70 kuesioner yang disebarkan kepada siswa, 35 kuesioner yang disebarkan kepada guru pendamping.

Dari 70 kuesioner yang disebarkan kepada siswa, ada 56 kuesioner yang kembali. Sedangkan 35 kuesioner yang disebarkan kepada guru, ada 32 kuesioner yang kembali pada Tabel 3.

Tabel 3. Persentase Respon Guru dan Siswa dalam Mengisi Kuesioner

\begin{tabular}{llll}
\hline Subjek & $\begin{array}{l}\text { Kuesioner } \\
\text { disebar }\end{array}$ & $\begin{array}{l}\text { Kuesioner yang } \\
\text { kembali }\end{array}$ & $\begin{array}{l}\text { Persentase } \\
(\%)\end{array}$ \\
\hline Guru & 35 & 32 & $91,43 \%$ \\
\hline Siswa & 70 & 56 & $80 \%$ \\
\hline
\end{tabular}

Peneliti melihat respon yang positif dan baik dari guru maupun siswa untuk mengisi kuesioner saat kegiatan telah selesai. Hasil scoring dari kuesioner dianalisis dengan mencari mean dari skor kuesioner yang diperoleh. Mean digunakan untuk mengetahui nilai hitung rata-rata. Penghitungan mean tersebut ditentukan dengan cara mengombinasi bobot nilai tiap jawaban responden berdasarkan nilai maksimum dan nilai minimum, dapat diketahui persepsi responden.

Tabel 4. Rata-rata Keseluruhan

\begin{tabular}{|c|c|c|c|c|c|}
\hline Subjek & $\begin{array}{l}\Sigma \\
\text { Responden }\end{array}$ & $\begin{array}{l}\text { skor } \\
\text { kuesioner }\end{array}$ & Total & $\begin{array}{c}\text { Rata-rata } \\
\text { Keseluruhan }\end{array}$ & $\begin{array}{l}\text { Grand } \\
\text { Mean }\end{array}$ \\
\hline Guru & 32 & $\mathrm{I} 204$ & \multirow{2}{*}{4156} & \multirow{2}{*}{47,23} & \multirow[b]{2}{*}{3,15} \\
\hline Siswa & 56 & 2952 & & & \\
\hline
\end{tabular}

Peneliti membagi persepsi responden menjadi 4 kategori, yakni persepsi sangat negatif, negatif, positif, dan sangat positif. Hal ini dapat terlihat digaris bilangan yang menunjukkan rentang 0-4. Garis bilangan kategori persepsi dibagi menjadi 4 . Nilai tengahnya adalah ratarata keseluruhan. Lalu masing-masing dibagi sama besar. Persepsi sangat negatif jika grand mean 0-I,57. Persepsi negatif jika grand mean antara I,58-3,I5. Persepsi positif jika grand mean antara 3,16-3,58. Persepsi sangat positif jika grand mean antara 3, 57 - 4 tertera pada Tabel 5.

Tabel 5. Persepsi Guru dan Siswa terhadap Conservation Scout

\begin{tabular}{ccccl}
\hline Subjek & $\begin{array}{c}\Sigma \\
\text { Responden }\end{array}$ & $\begin{array}{c}\Sigma \text { skor } \\
\text { kuesioner }\end{array}$ & $\begin{array}{c}\text { Grand } \\
\text { Mean }\end{array}$ & keterangan \\
\hline Guru & 32 & $\mathrm{I} 204$ & 2,50 & negatif \\
\hline Siswa & 56 & 2952 & $3,5 \mathrm{I}$ & positif
\end{tabular}

Guru memperlihatkan persepsi yang negatif terhadap program conservation scout. Guru memberikan beberapa komentar yang bersifat teknik pelaksanaan Conservation scout bukan mengenai isi atau esensi program. Pada kolom komentar, guru menuliskan saran disediakannya 
fasilitas snack dan makan siang untuk siswa. Ada juga guru yang menyarankan fasilitas antar jemput dari PSL ke sekolah.

Siswa memberikan persepsi yang positif pada program conservation scout. Mereka mengikuti setiap kegiatan dengan baik dan memberikan feedback yang positif pada kolom komentar. Salah satu siswa menuliskan "saya senang karena mendapat bimbingan dan banyak ilmu pengetahuan, dan saya melakukan beberapa eksperimen yang membuat saya ingin selalu mengikuti kegiatan conservation scout".

Keberhasilan program Conservation scout mencapai 53, $125 \%$ diukur dari total sekolah yang mengirimkan siswa yang berhasil melaksanakan peer tutoring dan kampanye di sekolah. dari 32 sekolah, ada 17 sekolah yang siswanya berhasil menjadi duta konservasi lingkungan.

\section{Simpulan}

Penelitian ini membuktikan persepsi yang negatif dari guru pendamping dan persepsi positif dari siswa yang menjadi peserta kegiatan Conservation scout di Pusat Studi Lingkungan, Universitas Sanata Dharma, Yogyakarta. Selain itu, ada respon sangat positif dari SD mitra PGSD, Universitas Sanata Dharma pada kegiatan conservation scout. Kegiatan Conservation scout dirasa bisa menjadi sarana penanaman karakter cinta lingkungan dan peduli konservasi pada siswa SD karena dari 32 SD yang menjadi peserta conservation scout, ada 53 , I2 \% yang siswanya berhasil menjadi duta konservasi lingkungan.

\section{Daftar Pustaka}

Arikunto, Suharsimi. 2010. Prosedur Penelitian Suatu Pendekatan Praktik. Jakarta: Rineka Cipta.

Azwar, Saifuddin. 1997. Metode Penelitian. Yogyakarta: Pustaka Pelajar

Davis, Julie. (1998) "Young Children, environmental education and the future". Journal of Education and the Environment, (II).

Prawirohardjo, Sarwono. 2010. Dua Abad Mengungkap Kekayaan Flora dan Ekosistem Indonesia. Jakarta : LIPI.

Sign, H.; Rahman, S.A. 20I0. An approach of environmental education by Non-Goverment Organizations (NGOs) in Biodiversity Conservation. J Soc Behav Sci 42: I44-I52

Thathong and Leopenwong. 20I4. The Development of Environmental Education Activities for Forest Resources Conservation for the Youth. J Soc and Behav Sci I I6:2266-2269 